\title{
Technical Efficiency of Milk Producers in Cattle Corridor of Uganda: Kiboga District Case
}

\author{
Teddy Triza Nakanwagi, Theodora S. Hyuha \\ Department of Agribusiness \& Natural Resource Economics, College of Agricultural and Environmental Sciences, \\ Makerere University, Kampala, Uganda \\ Email: trizan2002@yahoo.com, theohyuha@gmail.com
}

Received 10 April 2015; accepted 26 July 2015; published 29 July 2015

Copyright (C) 2015 by authors and Scientific Research Publishing Inc.

This work is licensed under the Creative Commons Attribution International License (CC BY). http://creativecommons.org/licenses/by/4.0/

c) (i) Open Access

\begin{abstract}
Overall objective of the study was to analyze technical efficiency and its determinants among milk producers in cattle corridor parts of Kiboga district. Stochastic frontier approach was employed to analyze technical efficiency and Tobit model regression to establish determinants of technical efficiency. The study used cross sectional edited data of 190 randomly sampled respondents from the three sub counties of Dwaniro, Kapeke and Lwamata. Milk producers achieved average technical efficiency level of $68 \%$. Average technical efficiency indicated that milk producers were operating below the production frontier and were not technically efficient but had potential to improve. Determinants of technical efficiency were herd size, improved cows, hired labour, land ownership, water source and extension services. Policies that will lead to increased investment in valley tanks, increased investment in cross/exotic cows and increased investment in provision of extension are recommended by the study.
\end{abstract}

\section{Keywords}

Cattle Corridor Milk Producers, Technical Efficiency, Stochastic Frontier Approach

\section{Introduction}

In Uganda, milk is largely produced in the cattle corridor. Occupants of the cattle corridor are known traditional cattle keepers and own $65.4 \%$ of the total national cattle herd [1]. [2] noted that growth in milk volume in Uganda is attributed to growth in cattle numbers rather than cow productivity. This makes occupants of the cattle corridor, the backbone of the dairy subsector. [3] noted that African agriculture suffers from low productivity and production 
due to use of low yielding technologies for example use of local cow breeds in milk production which is common in the cattle corridor. According to [4], fertility rate in rural areas stood at 6.8 which contribute to decrease in grazing land yet it is a key factor in livestock production. Cattle corridor also suffers from water shortages due to erratic rainfall [5], greatly affecting milk production. Therefore, efficient use of available resources [6] becomes a priority in the cattle corridor if the country is to sustain its milk demand resulting from rapid population growth.

Demand for goods including milk and its products is stimulated by increase in population. Uganda has a high fertility rate of 6.2 children per woman [7] and an annual growth rate of 3.3\% provides opportunities for milk producers, especially since milk which is recommended for infant feeding. There is also a growth in the number of milk processing factories since the liberalization of the subsector in 1993, this increases competition for milk and can only be good news to the subsector. And according to livestock data innovation in Africa brief by [8], Sameer Agriculture and Livestock Limited, the largest milk processor in the country, identified insufficient milk supply as a hindrance to satisfying its milk demand, hence, a need to increase milk production in the country.

To sustain the growing demand for milk, understanding technical efficiency of the country's largest milk producers found in the cattle corridor is vital. But there is scanty empirical evidence on technical efficiency of milk producers in Uganda especially in cattle corridor.The only study found on frontier and technical efficiency of milk producers in Uganda was by [9] titled "Measuring and explaining technical efficiency of dairy farms: a case study of smallholder farms in East Africa”. In their study, Data Envelopment Analysis (DEA) was employed to estimate technical efficiency. This study used Stochastic Frontier Approach (SFA) to analyse technical efficiency of milk producers in the cattle corridor. Stochastic frontier approach is widely used in agricultural economics studies [10] because of its ability to effectively estimate technical efficiency while accounting for technical inefficiency factors that are farm specific and random factors that influence observed technical efficiency level that are beyond the producer's control. This research paper sought to contribute to technical efficiency literature of milk producers in Uganda by quantifying the level of technical efficiency for sampled milk producers in three sub counties of Kiboga district which are predominantly located in the cattle corridor stretch. Technical efficiency measurement is the most studied component of productivity efficiency because it can help to generate valuable information for policy formulation and farm level decisions focused on the improvement of farm performance [11]. It is thought that milk producers' and farm characteristics observed to influence technical efficiency in Kiboga district will be used to draw recommendations that will help policy makers to formulate appropriate policies that stimulate efficient milk production and competiveness in the dairy subsector.

Therefore, the objectives of this study were: 1 ) to estimate technical efficiency levels of milk producers; 2) to identify factors that cause variation in technical efficiencies of milk producers; 3 ) to identify appropriate policy recommendations.

\section{Materials and Methods}

\subsection{Study Area and Sample Selection}

The study was based on cross section primary data collected in 2012 from 190 milk producers through direct interview method using pre-tested questionnaires in three sub counties of Kiboga District, one of the districts found in the cattle corridor of Uganda. The district is divided into two geographical areas that respectively support pastoral and crop cultivation along the right and left hand side of Kampala-Hoima road. Its proximity to Kampala, the capital of Uganda compared to other cattle corridor districts, makes it a strategic milk hub and is likely to be crucial milk supplier for milk processing industries located in Kampala.

The selection of Dwaniro, Kapeke, and Lwamata sub counties was purposive considering that they are largely located in the cattle corridor stretch and predominantly occupied by pastoral communities. These pastoral communities depend on cattle keeping as the main source of income. Milk producers in Kapeke and Dwaniro were randomly selected from registered and non-registered members who deliver milk at the cooperative and in Lwamata milk producers were randomly selected from a list that was generated by a government agricultural agent in the sub county.

\subsection{Data Analysis}

Technical efficiency was analysed through estimation of the Stochastic Frontier Production function using the Cobb Douglas functional form was used to analyse the technical efficiency of milk producers in the study area. Then tobit regression model was used to analyse determinants of technical efficiency. Hence a two-stage approach was employed in this study. 


\subsection{Empirical Model Specification}

Estimation technical efficiency levels is preceded by estimation of a production frontier, which in this study was a stochastic production frontier. But in order to estimate the stochastic production frontier, a production function must be specified. Cobb-Douglas and translog functions are the main functions used in specifying the stochastic frontier production and for this study, Cobb-Douglas function was chosen in which both output and inputs were expressed in logarithmic form.

Cobb-Douglas function form is preferable to other forms when three or more independent variables are involved [12]. [13] stated that its simplicity and widespread use in agricultural economics outweigh its drawbacks and it is less affected by multicollinearity problem and suffers less from degrees of freedom.

The explicit Cobb-Douglas stochastic frontier production function is given in the equation below:

$$
\ln Y=\beta_{0}+\beta_{1} \ln X_{1}+\beta_{2} \ln X_{2}+\beta_{3} \ln X_{3}+\beta_{4} \ln X_{4}+\beta_{5} \ln X_{5}+\beta_{6} \ln X_{6}+\beta_{7} \ln X_{7}+v-u
$$

ln = Logarithm to base e, $\beta_{0}=$ Intercept common to all producers, $Y=$ Average annual milk output per farm (L), $X_{1}=$ Number of adult local cows, $X_{2}=$ Number of cross/exotic bred cows, $X_{3}=$ salt $(\mathrm{Kg}), X_{4}=$ Veterinary goods and service cost incurred in Uganda shilling (UGX), $X_{5}=$ Human-labor (person-days), $X_{6}=$ Assets value (UGX), $X_{7}=$ Pasture land (acres). $v$ Measures the random variability in production that cannot be influenced by producers. That is to say, it captures stochastic effects which reduce a producer's technical efficiency score besides the controllable factors that reduce technical efficiency. It is assumed to be independently and identically distributed random error, $v \sim N\left(0, \sigma_{v}^{2}\right)$. On the other hand, $u$ measures the shortfall of output $(Y)$ from its maximal possible value given by the stochastic frontier, $f\left(X_{i}, \beta_{i}\right)+v_{i}$. It is a one-sided error term of non-negative random variable associated with technical inefficiency in production.

To effectively separate the technical inefficiency error term $(u)$ from the random error term $(v)$ in the composed error $\varepsilon=v-u$; [14] proposed that a distribution assumption is made for the mean and mode of $u$. The most commonly applied distribution assumptions are; half-normal and exponential. Half-normal distribution was assumed for $u$, and still $u$ is assumed to be independently and identically distributed, $u \sim N\left(0, \sigma_{u}^{2}\right)$.

Maximum likelihood estimation of explicit Cobb-Douglas stochastic frontier production function yields consistent estimators for $\beta, \lambda, \sigma^{2}$; where $\beta$ is a vector of unknown parameters, lamba $(\lambda)$ is the ratio of the standard error of $u\left(\sigma_{u}\right)$ to the standard error of $v\left(\sigma_{v}\right)$, that is $\lambda=\sigma_{u} / \sigma_{v}$ and $\sigma^{2}=\sigma_{v}^{2}+\sigma_{u}^{2}$. Based on $\lambda$, the value of gamma $(\gamma)$, which measures the effect of technical inefficiency in the variation of observed output can be derived, $\gamma=\lambda^{2} /\left[1+\lambda^{2}\right]$. The value of gamma is bounded between 0 and 1 like technical efficiency. A gamma $(\gamma)$ value which is zero or close indicates that sampled milk producers had no technical inefficiency. However, a value that is close to one, indicates variation in observed output is due to the technical inefficiency of the sampled milk producers rather than uncontrollable factors.

Technical efficiency of the $\mathrm{i}^{\text {th }}$ milk producer is the ratio of the observed output to the frontier output. Cancelation of stochastic parts in the "Equation (2)", results in "Equation (3)."

$$
\begin{gathered}
\mathrm{TE}=f\left(X_{i}, \beta_{i}\right) \exp \left(v_{i}\right) \exp \left(-u_{i}\right) / f\left(X_{i}, \beta_{i}\right) \exp \left(v_{i}\right) \\
\mathrm{TE}=\exp \left(-u_{i}\right)
\end{gathered}
$$

Technical efficiency in the estimated model is 1-technical inefficiency score. The parameters of the explicit Cobb-Douglas stochastic frontier production function were estimated using frontier model in STATA analysing software. Descriptive statistics of variables used in the frontier production function are presented in Table 1.

\subsection{Factors That Influence Technical Efficiency}

In the second stage analysis, obtained technical efficiency score estimates (TE) from maximum likelihood estimation of the stochastic frontier function were regressed against selected farm and producer characteristics using a tobit regression model. Tobit model was preferred to OLS because efficiency scores are discrete in nature. Further explanation of tobit model can be found in [15] [16].

$$
\begin{aligned}
Y^{*}= & \alpha_{0}+\alpha_{1} X_{1}+\alpha_{2} X_{2}+\alpha_{3} X_{3}+\alpha_{4} X_{4}+\alpha_{5} X_{5}+\alpha_{6} X \alpha_{6}+\alpha_{6} X_{6}+\alpha_{7} X_{7} \\
& +\alpha_{8} X_{8}+\alpha_{9} X_{9}+\alpha_{10} X_{10}+\alpha_{11} X_{11}+\in
\end{aligned}
$$

where by: $Y^{*}=$ Technical efficiency score of the milk producer, $X_{1}=$ Age of household head (Years), 
Table 1. Descriptive statistics of variables in cobb-douglas stochastic production frontier function.

\begin{tabular}{cccc}
\hline Variable & \multicolumn{2}{c}{ Descriptive Characteristics (n=190) } \\
\cline { 2 - 3 } Milk Output & Unit & Mean & SD \\
Local Cows & Litres & 17,700 & 20,500 \\
Cross/Exotic & Number & 24.1 & 24.4 \\
Salt & Number & 11.7 & 21.6 \\
Veterinary Cost & Kg & 980 & 1110 \\
Labour & UGX & $2,220,000$ & $2,840,000$ \\
Farm Assets & Person Days & 478 & 439 \\
Pasture Land & UGX & $2,910,000$ & 77.5 \\
\hline
\end{tabular}

Survey Data 2012 (All values are annual and UGX = Uganda Shilling).

$X_{2}=$ Household size, $X_{3}=$ Education level (Years), $X_{4}=$ Herd size (Number), $X_{5}=$ Dummy for possession of Cross/exotic Cow, $X_{6}=$ Dummy for hired labor use, $X_{7}=$ Dummy for land ownership, $X_{8}=$ Dummy for water valley tank/mindam at farm, $X_{9}=$ Extension service dummy, $X_{10}=$ Group membership dummy and $X_{11}=$ Town Distance $(\mathrm{Km}) . \alpha$-parameters to be estimated associated with explanatory variables. $\epsilon$ is the error term associated with the model.

Age variable was included to estimate the impact of milk producers' age on technical efficiency and it was used as a proxy for producer's experience. Age of the producer may affect the technical efficiency negatively following the saying that "you cannot teach an old dog a new trick". Older producers may insist on sticking to old practices [17] or take long to accept new technologies that would improve operation efficiency as they tend to be risk averse. [18] obtained results which favored technical efficiency of young adult farmers. On the other hand, it is argued that age is associated with accumulation of experience and wealth. And through experience, producers may improve their farm managerial skills which in turn may improve their technical efficiency [19]. Accumulated wealth facilitates acquisition of key factor inputs, technology adoption and asset [20]. Thus, the expected sign in the model is ambiguous.

Household size variable was included to determine effect of number of people in the household on technical efficiency of milk producers. Household size is relevant in milk production in the cattle corridor. It provides family labor which constitutes the bulk of labor supply in developing countries. Household size also influences household members to increase food production in order to meet consumption and marketing surplus needs. Considering the importance household in providing yet labor is a key factor of production, household size was expected to have a positive relation with technical efficiency as observed in the studies of [13] [21].

Education level is the number of years of formal schooling of the household head. Education increases producer's information acquisition hence increasing their decision making abilities [22]. Education improves a person's ability in interpreting and understanding information regarding new technologies, and executing instructions. Rural milk producers need to be able to read labels on veterinary drugs especially expiry dates. Several studies have observed a statistically significant and positive relationship between education and efficiency [23]-[27]. Education level therefore, was expected to have a positive effect on technical efficiency of milk producers though it may not do much to affect technical efficiency because majority of milk producers in cattle corridor receive practical skills on cattle operations and management from childhood.

Herd size may increases technical efficiency by providing advantages of economies of scale. Producers with large herd sizes are more likely to be committed to their farms, than those with small herd sizes who are more likely to diversify into nonfarm employment [28]. Holding a contrary view, [29] noted that owners of small scale farms tend to work on their farms and appropriate the full benefits of their efforts unlike large scale farmers who use hired labor which is rarely found to be least concerned with farm progress. Results of Herd size effect on efficiency for [30] was positive and statistically significant while [31] observed a significant and negative relationship between herd size and technical efficiency in milk production in underdeveloped production 
environment of India. Herd size was expected to affect technical efficiency in either direction.

Possession of cross/exotic Cow is a dummy variable indicating whether the producer had at least one cross/ exotic bred cow for milk production. This variable was included to capture extent of diffusion of cross/exotic breeds among traditionally known cattle keepers of local breeds. Another reason why the variable was included was to determine if cattle keepers in the cattle corridor keep cattle for commercial milk production. [32] observed a significant and positive relation between cross bred animals and technical efficiency while assessing technical efficiency and supply chain practices in India. It was expected that possession of improved cows at the farm would positively affect technical efficiency.

Hired labor is a dummy variable indicating that a producer employed hired labor for farm activities in the study year. The variable was included to determine if farms that used hired labor had a significant advantage over farms which relied only on family labor. Hired labor improves the quality of labor at the farm as hired workers are more likely to concentrate on farm activities for which they were hired to perform. Milk producers in the corridor operate large herds of cattle; gaining access to hired labor is likely to increase their efficiency in operations. [33] [34] both positive and statistically significant results for households in Northern Ghana and small milk production in Cukurova region Turkey respectively. This study expected hired labor to have a positive impact on producer's efficiency.

Land ownership is a dummy variable indicating whether the producer owned the land on which the farm was located. Owning land where the producer can graze cattle removes expenses the farmer would have incurred in renting land and also enables the farmer to establish permanent structures vital in the management of the farm like valley tanks that ensure constant supply of water for cattle. [35] result on the relationship between land ownership and technical efficiency was positive and significant $(\mathrm{p}>0.005)$. It was therefore, expected that land ownership variable would have a positive impact on technical efficiency.

Valley tank is a dummy variable that indicate presence of a watersource for cattle at the farm. The variable was included to capture socioeconomic developments among traditional pastoralists who used to move cattle for long distances in such of water. Presence of water sources at farms in a way indirectly indicate that milk producers in the cattle corridor are settled communities and it also indicates government's commitment to the development of livestock sector. Livestock require a lot of water especially during the dry months, putting tremendous pressure on livestock producers in the cattle corridor which has scarce water sources. Therefore, a water source on the farm improves technical efficiency by saving time and resources that would have been spent looking for water especially during the dry season. It also improves management of improved cattle breeds which are vulnerable to environmental stress hence maintaining relative milk production throughout the year. [36] result of the dummy for water source at the farm was statistically significant and positively related with technical efficiency of smallholder dairy farmers in Kenya. Having a valley tank at the farm was hypothesized to have a positive relation with technical efficiency of sampled milk producers.

Extension services is a dummy variable indicating whether the milk producer received extension services in form of dairy trainings and farm veterinary visits from government or development partners' extension service personnel in the study year 2012. Extension services increase efficiency through improving farm their management skills and knowledge acquisition on new practices [37]. It is likely that though there is low extension service spread in cattle corridor areas due to few veterinary extension service personnel and long distances producers have to travel to attend organized dairy trainings, producers that had received extension services were more likely to have high levels of technical efficiency levels.

Group membership is a dummy variable indicating whether a milk producer belongs to a dairy cooperative or association and actively participates in its meetings and activities. Belonging and participating in producer cooperative or group is associated with market and technology information acquisition [38]. It is also associated with knowledge sharing which may improve farmer's decision making regarding input price and output prices and adoption of a new technology that can improve operations efficiency. [39] [40] both found membership and participation in cooperative societies was related to increased efficiency. Though [41] results for membership in a cooperative were negative and insignificant, it was postulated that group membership would have a positive impact on technical efficiency of producers.

Town distance is the distance in kilometers a producer or farm workers travel to the nearest town centers to sell milk and buy production inputs like milk cans, veterinary drugs, salt and others. Long distances reduces the price of marketed milk and increase input prices as a result of the high cost of transportation incurred in moving milk output and inputs [17]. Also long distances coupled with bad roads in rural areas discourage both producers 
and extension service personnel from receiving and giving extension services [36]. [42] observed a negative and significant relationship between distance to markets and technical and allocative efficiency of small dairy farmers in Swaziland. Town distance is thus expected to negatively correlate with technical efficiency.

Descriptive statistics of variables used in second stage analysis to determine factors that influence technical efficiency are given in Table 2.

\section{Result and Discussion}

\subsection{Estimation of the Cobb-Douglas Stochastic Production Frontier}

Table 3 presents the maximum likelihood estimates for parameters of Cobb-Douglas stochastic production frontier of sampled milk producers. Estimation of input variables in logarithmic model resulted in partial coefficient elasticities [43] [44]. Therefore, estimated coefficient parameters in the stochastic production Cobb-Douglas frontier represent a percentage change in the dependent variable as a result of percentage change in the independent variables. Annual milk output per farm was influenced positively and significantly by number of cross/exotic cows, quantity of salt, veterinary costs, labor, farm assets and pasture land while number of local cows though included in the production function had no significant effect on milk output.The value of lambda ( $\lambda$ ) shown in Table 3, was 2.2 which is greater than 1, such a result according to [35] [45] indicate a good fit for the estimated model and the correctness of the distributional assumptions. Lamba also indicated that a great part of the residual variation in output is associated with technical inefficiency rather than measurement error associated with uncontrollable factors related to the production process. The value of gamma $(\gamma)$ was 0.82 and was statistically significant at $1 \%$, implying that $82 \%$ of the variation in milk output of the respondents was due technical inefficiency term $u$ rather than random error $v$ associated with uncontrollable factors which affect production. This explains why ordinary least squares (OLS) or an average production function was not a suitable specification for sampled milk producers. That means that sampled milk producers were not operating on the production frontier or were technically inefficiency. The effect of the technical inefficiency in the stochastic production frontier resulted in technical efficiency scores which were less than 1 across the sample as shown in Table 4.

Summary statistics of technical efficiency estimates obtained from the stochastic frontier model and their frequency distributions are presented in Table 4. Results show that milk producers achieved average technical efficiency of $68 \%$, with minimum and maximum technical efficiency score of $22 \%$ and $92 \%$ respectively. Results

Table 2. Desriptive statistics of variables used in tobit regression model in second stage analysis.

\begin{tabular}{cccc}
\hline Variable & \multicolumn{2}{c}{ Descriptive Characteristics $(\mathrm{n}=190)$} & Mean \\
\cline { 2 - 4 } Producer Age & Unit & 45.0 & 11.4 \\
Household Size & Years & 9.0 & 4.4 \\
Education Level & Number & 4.8 & 4.4 \\
Herd Size & Formal Schooling Years & 71.8 & 64.8 \\
Town Distance & Number & 6.5 & 6.5 \\
& Km & & \\
Possession of Cross/Exotic Cow & Percentages & 53 & 50 \\
Hired Labor Use & $1=$ Yes, $0=$ No & 69 & 46 \\
Land Owership & $1=$ Yes, $0=$ No & 72 & 45 \\
Valley Tank & $1=$ Yes, $0=$ No & 80 & 40 \\
Extension Services & $1=$ Yes, $0=$ No & 67 & 47 \\
Group Membership & $1=$ Yes, $0=$ No & 70 & 50 \\
\hline
\end{tabular}

Survey Data 2012. 
Table 3. Maximum likelihood estimation of the cobb-douglas stochastic production frontier.

\begin{tabular}{cccc}
\hline \multirow{2}{*}{ Variable } & \multicolumn{3}{c}{$\mathrm{n}=190$} \\
\cline { 2 - 4 } Constant & Unit & Coefficient & t-ratio \\
Local Cows & Number & $2.133^{* * * *}$ & 2.92 \\
Cross/Exotic & Number & -0.019 & -0.59 \\
Salt & Kg & $0.189^{* * * *}$ & 6.77 \\
Veterinary Cost & UGX & $0.149^{* * *}$ & 2.69 \\
Labour & Person Days & $0.258^{* * *}$ & 4.85 \\
Farm Assets & UGX & $0.161^{* * *}$ & 2.85 \\
Pasture Land & Acres & $0.076^{* * *}$ & 2.05 \\
$\sigma_{v}$ & & $0.125^{* * *}$ & 3.32 \\
$\sigma_{u}$ & & 0.250 & \\
$\sigma^{2}$ & & 0.540 & \\
$\gamma$ & & 0.354 & \\
$\lambda$ & & 0.820 & \\
Wald chi2 (7) & & 2.164 & \\
\hline
\end{tabular}

Survey Data 2012, ${ }^{* *}=5 \%$ and ${ }^{* * *}=1 \%$.

Table 4. Distribution of technical efficiency scores of the sampled milk producers.

\begin{tabular}{cccc}
\hline & Descriptive Statistics $n=190$ & & \\
\hline Technical Efficiency Score Range (\%) & Frequency & Farm \% \\
\hline$<30$ & 3 & 1.6 \\
$31-40$ & 10 & 5.3 \\
$41-50$ & 11 & 5.8 \\
$51-60$ & 35 & 18.4 \\
$61-70$ & 34 & 17.9 \\
$71-80$ & 57 & 30.0 \\
$81-90$ & 38 & 20.0 \\
$>90$ & 2 & 1.1 \\
68.2 & Mean & \\
21.8 & Min & \\
92.4 & Max & \\
\hline
\end{tabular}

Survey Data 2012.

also indicated that approximately $31 \%$ of milk producers operated below average technical efficiency range while $50 \%$ of the milk producers operated above average technical efficiency obtained. Results also show that all milk producers were producing below the production frontier since the maximum value of technical efficiency estimate obtained was $92 \%$.

\subsection{Determinants of Technical Efficiency}

Determinants of technical efficiency scores that were obtained from maximum likelihood estimation of the Cobb-Douglas stochastic production frontier, were analyzed using a Tobit regression model and the results are 
presented in Table 5. Estimated technical efficiency scores were used as the dependent variable in the model. Tobit regression model analysis resulted in likelihood ratio that was significant at $1 \%\left(x_{\text {critical }}^{2}=345.5\right)$, which indicated that variables that were considered for the study adequately explain the efficiency levels [16] of the sampled milk producers.

Observed coefficient signs from the Tobit regression analysis have a direct relationship with technical efficiency. Unlike in the single step method, in which the inefficiency model is simultaneously estimated with stochastic frontier production; where coefficients signs have an inverse relationship with technical efficiency.

Coefficients associated with age, education level, household size and group membership and town distance had no statistically significant effect on milk producers' technical efficiency and no further discussion is made concerning them.

Coefficient associated with herd size was positive and statistically significant which implies that large scale farms were more technically efficient than small scale farms. The finding collaborates with findings of [46] that observed positive and significant relationship between flock size and technical efficiency of poultry egg producers in Oyo state, Nigeria. This finding could be explained by supposing that large scale farmers are more likely to be risk takers, technology adopters [46]), have easy access to credit, training and technical support [16].

Possession of cross/exotic cow had a positive and significant impact on technical efficiency of milk producers. The results of the study were consistent with findings of [32] that observed possession of crossbred animals in livestock had a negative relationship with technical inefficiency or a positive relationship with technical efficiency for dairy farms in India. This implies that a farm that was using at least one improved cow for milk production had higher technical efficiency than a farm which was relying only on local cows for milk production.

Hired labor use had a positive and significant impact on producers' technical efficiency. The results are consistent with those obtained by [33] [34]. There is a high probability that technical efficiency of milk producers in the cattle corridor could be increased if producers take advantage of hired labour especially since milk producers in the cattle corridor operate large farms/herds of cattle averaging at seventy two-heads of cattle as indicated in Table 2.

Land ownership coefficient was positive and statistically significantly related to technical efficiency of milk producers in the study area. The results were similar with results of [35] but disagreed with results of [17] which show that households that rented land achieved higher technical efficiency than households that did not rent land. For milk producers in cattle corridor operating large herds of cattle, renting land would be expensive.

Possession of a water valley tank at the farm had a positive and statistically significant effect on technical efficiency levels of the sampled milk producers. The results resonate with [36] who observed that the dummy for

\begin{tabular}{lccc} 
Table 5. Determinants of technical efficiency. & & \\
\multicolumn{1}{c}{ Variable } & Unit & Coefficient & t-Ratio \\
\cline { 2 - 4 } & & $7.988^{* * *}$ & 53.93 \\
\hline Constant & Years & 0.00057 & 0.22 \\
Producer Age & Number & 0.00130 & 0.19 \\
Household Size & Formal Schooling years & 0.00136 & 0.19 \\
Education Level & Number & $0.00941^{* * *}$ & 18.03 \\
Herd Size & Km & -0.00000 & -0.00 \\
Town Distance & $1=$ Yes, $0=$ No & $0.33142^{* * *}$ & 5.61 \\
Possession of Cross/Exotic Cow & $1=$ Yes, $0=$ No & $0.23836^{* * *}$ & 3.22 \\
Hired Labor use & $1=$ Yes, $0=$ No & $0.19085^{* * *}$ & 2.95 \\
Land Owership & $1=$ Yes, $0=$ No & $0.40376^{* * *}$ & 5.00 \\
Valley Tank & $1=$ Yes, $0=$ No & $0.17942^{* * *}$ & 2.72 \\
Extension Services & $1=$ Yes, $0=$ No & 0.06143 & 0.95 \\
Group Membership & & 0.662 & \\
Adjusted Pseudo R & & \\
\hline
\end{tabular}

Survey Data 2012, ${ }^{* * *}=1 \%$. 
source of water at the farm was negative and statistically significant at reducing inefficiency among dairy farmers in Kenya. [12] results also revealed that irrigation was important in rice cultivation and farmers whose land was under irrigation produced rice more efficiently. Agricultural production in both crops and animals is water intensive and water availability on the farm in every sense improves technical efficiency by saving time and resources that would have been spent looking for water especially during the dry season in case of livestock production.

The estimated coefficient of extension services was positive and its impact on technical efficiency was statistically significant. The obtained result is consistent with results of [46] [47]. This implies that extension services receipt help in improving technical efficiency of milk producers sampled. The advice given by the extension agents during trainings and farm visits helps the producers to improve their management skills and to acquire knowledge on new practices [37].

\section{Conclusions and Recommendations}

Overall milk producers achieved average technical efficiency of $68 \%$ meaning that there is $32 \%$ potential of milk producers to improve their technical efficiency. Average technical efficiency level of $68 \%$ indicates that milk producers on average were operating below the production frontier and were not technically efficient.

Major determinants of technical efficiency among milk producers were water source/valley tank at farm and possession of cross/exotic cows, attributed by the large coefficient values as compared to those of other variables in the model. But hired labour use, land ownership, farm water source and access to extension services too had a positive and statistically significant effect on technical efficiency of sampled milk producers.

Therefore, the study recommends policies that will lead to increased investment in valley tanks to increase water access in the cattle corridor. It also recommends increased investment in cross/exotic cows by milk producers and increased investment in provision of extension services by Government and partner institutions.

\section{Acknowledgements}

The study acknowledges Belgium Technical Cooperation (BTC) in Uganda for sponsorship.

\section{References}

[1] World Bank (2011) Uganda’s Dairy Supply Chain: Risk Assessment.

[2] Elepu, G. (2007) Policy Change in Dairy Marketing in Uganda and East Africa: Economic Impact and Pathways to Influence from Research. A Draft Report Submitted to Association for Strengthening Agricultural Research in Eastern and Central Africa.

[3] Nkamleu, G.B., Gokowski, J. and Kazianga, H. (2003) Explaining the Failure of Agricultural Production in Sub-Saharan Africa. The 25th International Conference of Agricultural Economists, Durban.

[4] Uganda Bureau of Statistics (2011) The 2011 Uganda Demographic and Health Survey.

[5] Stark, J. (2010) Climate Change and Conflict in Uganda: The Cattle Corridor and Karamoja. United States Agency for International Development.

[6] Yu, B. and Nin-Pratt, A. (2011) Agricultural Productivity and Policies in Sub-Saharan Africa. 2011 Annual Meeting, 24-26 July 2011, Pittsburgh.

[7] UNICEF (2012) Uganda Fast Facts.

[8] World Bank, FAO, ILRI and AU-IBAR (2011) Livestock Data Innovation in Africa BRIEF.

[9] Gelan, A. and Muriithi, B. (2010) Measuring and Explaining Technical Efficiency of Dairy Farms: A Case Study of Smallholder Farms in East Africa. The 3rd Conference of African Association of Agricultural Economists Africa and the Global Food and Financial Crises.

[10] Haider, M.Z., Ahmed, S. and Mallick, A. (2011) Technical Efficiency of Agricultural Farms in Khulna, Bangladesh: Stochastic Frontier Approach. International Journal of Economics and Finance, 3. http://dx.doi.org/10.5539/ijef.v3n3p248

[11] Bravo-Ureta, B.E., Moreira, V.H., Arzubi, A.A., Schilder, E.D., Álvarez, J. and Molina, C. (2008) Technological Change and Technical Efficiency for Dairy Farms in Three Countries of South America. Chilean Journal of Agricultural Research, 68, 360-367. http://dx.doi.org/10.4067/S0718-58392008000400006

[12] Khai, H.V. and Yabe, M. (2011) Technical Efficiency Analysis of Rice production in Vietnam. Journal of ISSAAS, 17, 
135-146.

[13] Rahman, K.M.M., Mia, M.I.A. and Bhuiyan, M.K.J. (2012) A Stochastic Frontier Approach to Model Technical Efficiency of Rice Farmers in Bangladesh: An Empirical Analysis. The Agriculturists, 10, 9-19. http://dx.doi.org/10.3329/agric.v10i2.13132

[14] Jondrow, J., Knox Lovell, C.A., Materov, I.S. and Schmidt, P. (1982) On the Estimation of Technical Efficiency in the Stochastic Frontier Production Function Model. Journal of Econometrics, 9, 233-238. http://dx.doi.org/10.1016/0304-4076(82)90004-5

[15] Idris, N.D.M., Siwar, C. and Talib, B. (2013) Determinants of Technical Efficiency on Pineapple Farming. American Journal of Applied Sciences, 10, 426-432. http://dx.doi.org/10.3844/ajassp.2013.426.432

[16] Gonçalves, R.M., da Cruz Vieira, W., de Lima, J.E. and Gomes, S.T. (2008) Analysis of Technical Efficiency of Milk Producing Farms in Minas Gerais. Economia Aplicada, 12, 321-335. http://dx.doi.org/10.1590/S1413-80502008000200007

[17] Feng, S. (2008) Land Rental, Off-Farm Employment and Technical Efficiency of Farm Households in Jiangxi Province, China. NJAS: Wageningen Journal of Life Sciences, 55, 363-378. http://dx.doi.org/10.1016/s1573-5214(08)80026-7

[18] Singh, S. and Sharma, S. (2011) Measurement of Technical Efficiency in Dairy Sector of India: A Stochastic Frontier Production Function Approach. TMC Academic Journal, 5, 51-64.

[19] Basnayake, B.M.J.K. and Gunaratne, L.H.P. (2002) Estimation of Technical Efficiency and Its Determinants in the Tea Small Holding Sector in the Mid Country Wet Zone of Sri Lanka. Sri Lankan Journal of Agricultural Economics, 4, 137-150.

[20] Wadud, I.K.M. and ArRashid, H. (2011) Profit Efficiency and Farm Characteristics: Evidence from Rice Farmers in Bangladesh. Proceedings of the Barcelona European Academic Conference, Barcelona, 6-9 June 2011.

[21] Obwona, M. (2006) Determinants of Technical Efficiency Differentials amongst Small and Medium Scale Farmers in Uganda: A Case of Tobacco Growers. African Economic Research Consortium Research, Paper 152.

[22] Asefa, S. (2012) Analysis of Technical Efficiency of Crop Producing Smallholder Farmers in Tigray, Ethiopia. Munich Personal RePEc Archive, No. 40461.

[23] Al-Sharafat, A. (2013) Technical Efficiency of Dairy Farms: A Stochastic Frontier Application on Dairy Farms in Jordan. Journal of Agricultural Science, 5. http://dx.doi.org/10.5539/jas.v5n3p45

[24] Ashagidigbi, W.M., Sulaiman, S.A. and Adesiyan, A. (2011) Technical and Allocative Efficiency of Poultry Producers in Nigeria. Agricultural Journal, 6, 124-130. http://dx.doi.org/10.3923/aj.2011.124.130

[25] Oluwatusin, F.M. (2011) Measuring Technical Efficiency of Yam Farmers in Nigeria: A Stochastic Parametric Approach. Agricultural Journal, 6, 40-46. http://dx.doi.org/10.3923/aj.2011.40.46

[26] Taru, V.B., Lawal, H. and Tizhe, I. (2011) Technical Efficiency of Sole Cowpea Production in Adamawa State, Nigeria: A Cobb-Douglas Stochastic Frontier Function. Journal of Economics and International Finance, 3, 504-507.

[27] Sabaghi, M.A., Badavi, H. and Ommani, A.R. (2012) Comparison of the Efficiency of Traditional and Industrial Milk Production Units in Khuzestan Province. International Journal of Agricultural Science, Research and Technology, 1, 177-183.

[28] Bagamba, F., Ruerd, R. and Mariana, R. (2007) Determinants of Banana Productivity and Technical Efficiency in Uganda. International Food Policy Research Institute, Washington DC. http://dx.doi.org/10.2499/9780896291645RR155

[29] Food and Agriculture Organization (2012) Livestock Sector Development for Poverty Reduction: An Economic and Policy Perspective Livestock’s Many Virtues. FAO, Rome.

[30] Demircan, V., Binici, T. and Zulauf, C.R. (2010) Assessing Pure Technical Efficiency of Dairy Farms in Turkey. Agricultural Economics-Czech, 56, 141-148.

[31] Bardhan, D. and Sharma, L.M. (2013) Technical Efficiency in Milk Production in Underdeveloped Production Environment of India. SpringerPlus, 2, 65. http://dx.doi.org/10.1186/2193-1801-2-65

[32] Mor, S. and Sharma, S. (2012) Technical Efficiency and Supply Chain Practices in Dairying: The Case of India. Agricultural Economics-Czech, 58, 85-91.

[33] Abatania, L.N., Hailu, A. and Mugera, A.W. (2012) Analysis of Farm Household Technical Efficiency in Northern Ghana Using Bootstrap DEA. Proceedings of the 56th Annual Conference of the Australian Agricultural and Research Economics Society, Perth, 7-10 February 2012.

[34] Alemdar, T., Bahadir, B. and Oren, M.N. (2010) Cost and Return Analysis and Technical Efficiency of Small Scale Milk Production: A Case Study for Cukurova Region, Turkey. Journal of Animal and Veterinary Advances, 9, 744-847. http://dx.doi.org/10.3923/javaa.2010.844.847 
[35] Rahman, S.A. and Umar, H.S. (2009) Measurement of Technical Efficiency and Its Determinants in Crop Production in Lafia Local Government Area of Nasarawa State, Nigeria. Journal of Tropical Agriculture, Food, Environment and Extension, 8, 90-96.

[36] Majiwa, E.B., Kavoi, M.M. and Murage, H. (2012) Smallholder Dairying in Kenya: The Assessment of the Technical Efficiency Using the Stochastic Production Frontier Model. JAGST, 14.

[37] Awunyo-Vitor, D., Bakang, J. and Cofie, S. (2013) Estimation of Farm Level Technical Efficiency of Small-Scale Cowpea Production in Ghana. American-Eurasian Journal of Agricultural \& Environmental Sciences, 13, 1080-1087.

[38] Binam, J.N., Tonye, J. and Wandji, N. (2005) Sources of Technical Efficiency among Small Holder Maize and Peanut Farmers in Slash and Burn Agricultural Zone of Cameroon. Journal of Economic Cooperation, 26, 193-210.

[39] Fita, L., Trivedi, M.M., Patel, A.M., Tassew, B. and Joshi, C.G. (2013) Determinants of Technical Efficiency of the Dairy Farmers in Ada District of Oromia State, Ethiopia. Iranian Journal of Applied Animal Science, 3, 59-65.

[40] Omiti, J., Wanyoike, F., Staal, S.J., Delgado, C. and Njoroge, L. (2006) Will Small-Scale Dairy Producers in Kenya Disappear Due to Economies of Scale in Production? Proceedings of the International Association of Agricultural Economists Conference, Gold Coast, Australia, 12-18 August 2006.

[41] Uzmay, A., Koyubenbe, N. and Armagan, G. (2009) Measurement of Efficiency Using Data Envelopment Analysis (DEA) and Social Factors Affecting Technical Efficiency in the Dairy Cattle Farms within the Province of Izmir, Turkey. Journal of Animal and Veterinary Advances, 8, 1110-1115.

[42] Masuku, B.B. (2014) Technical and Allocative Efficiency of Smallholder Dairy Farmers in Swaziland. Journal of Economics and Sustainable Development, 5, 1-9.

[43] Cabrera, V.E., Solis, I.D. and del Corral, J. (2010) Determinants of Technical Efficiency among Dairy Farms in Wisconsin. Journal of Dairy Science, 93, 387-393. http://dx.doi.org/10.3168/jds.2009-2307

[44] Djokoto, J.G. (2011) Technical Efficiency of Agriculture in Ghana: A Time Series Stochastic Frontier Estimation Approach. Journal of Agricultural Science, 4, 154. http://dx.doi.org/10.5539/jas.v4n1p154

[45] Ojehomon, V.E.T., Ayinde, O.E., Adewumi, M.O. and Omotesho, O.A. (2013) Determinant of Technical Efficiency of New Rice for Africa (NERICA) Production: A Gender Approach. Ethiopian Journal of Environmental Studies and Management, 6, 453-460. http://dx.doi.org/10.4314/ejesm.v6i5.2

[46] Adedeji, I.A., Adelalu, K.O., Ogunjimi, S.I. and Otekunrin, A.O. (2013) Application of Stochastic Production Frontier in the Estimation of Technical Efficiency of Poultry Egg Production in Ogbomoso Metropolis of Oyo State, Nigeria. World Journal of Agricultural Research, 1, 119-123.

[47] Ahmad, M., Muhammad, R. and Ali, A. (1999) An Analysis of Technical Efficiency of Rice Farmers in Pakistani Punjab. Bangladesh Journal of Agricultural Economics, 22, 79-86. 